\title{
PENGARUH MODEL PEMBELAJARAN DISCOVERY LEARNING BERBASIS PENILAIAN PORTOFOLIO TERHADAP KOMPETENSI PENGETAHUAN MATEMATIKA SISWA KELAS IV
}

\author{
Md Rai Advina Christianti', I Wyn Wiarta ${ }^{2}$, I Gst. A. Oka Negara ${ }^{3}$ \\ 1,2,3 Jurusan Pendidikan Guru Sekolah Dasar, Universitas Pendidikan Ganesha, Singaraja, Indonesia \\ email: advinachristianti@gmail.com ${ }^{1}$, iwayan.wiarta@undiksha.ac.id², okanegaragustiagung@gmail.com
}

\begin{abstract}
Abstrak
Penelitian ini bertujuan untuk mengetahui pengaruh model discovery learning berbasis portofolio terhadap kompetensi pengetahuan matematika siswa kelas IV SD Gugus II Kuta Utara Tahun Pelajaran 2017/2018. Jenis penelitian ini adalah penelitian ekperimen semu dengan menggunakan desain penelitian Nonequivalent Control Group Design. Populasi dalam penelitian ini adalah seluruh siswa kelas IV SD Gugus II Kuta Utara tahun pelajaran 2017/2018 sebanyak 277 siswa. Sampel penelitian ditentukan dengan teknik random sampling. Sampel dalam penelitian ini adalah kelas IV SD No. 3 canggu sebagai kelompok ekperimen dan kelas IVC SD No. 1 Tibubeneng sebagai kelompok kontrol dengan jumlah masing-masing kelompok sebanyak 30 siswa setelah disetarakan dengan teknik matching. Metode pengumpulan data dalam penelitian ini adalah metode tes, dengan tes pilihan ganda biasa yang berjumlah 30 butir soal yang telah divaliditas. Analisis data menggunakan uji-t menunjukan bahwa terdapat perbedaan yang signifikan kompetensi pengetahuan matematika siswa yang dibelajarkan menggunakan model discovery learning berbasis portofolio dan siswa yang dibelajarkan menggunakan pembelajaran konvensional pada siswa kelas IV di SD Gugus II Kuta Utara Tahun Pelajaran 2017/2018. Hal tersebut dibuktikan dengan ( $\mathrm{t}_{\text {hitung }}=2,683>\mathrm{t}_{\text {tabel }}=2,021$ ) pada taraf signifikansi $5 \%$ dengan $\mathrm{dk}=\mathrm{n} 1+\mathrm{n} 2-2(30+30-2=56)$ dan rerata nilai kompetensi pengetahuan matematika siswa kelompok eksperimen 73,50 dan rerata nilai kompetensi pengetahuan matematika siswa kelompok kontrol 64,40. Dengan demikian, dapat disimpulkan bahwa terdapat pengaruh model discovery learning berbasis portofolio terhadap kompetensi pengetahuan matematika siswa kelas IV SD Gugus II Kuta Utara Tahun Pelajaran 2017/2018.
\end{abstract}

Kata kunci: discovery learning, portofolio, matematika

\begin{abstract}
This study is aim to determine the effect of discovery learning model besed on portofolio of mathematies knowledge competencies of IV grade students of elementary school Gugus II Kuta Utara academic year 2017/2018. This research is an quasi experiment design with Nonequvalent Control Group Design. Population in this research were all students of IV elementary school Gugus II Kuta Utara academic year 2017/2018 as many as 277 students. The sample of this research is the IV grade student of elementary school No. 3 canggu as experimental class and IVC grade student of elementary school No. 1 Tububeneng as control class with the total of each group as much as 30 students after equalized by matching technique. The method of data collection in this research is test method, with the usual double choice test amount of 30 items that have been validity. The data analysis using t-test shows that there is were significant differences of students mathematics knowledge competency which is learned by using discovery learning model besed on portofolio and students who ware taught by using conventional learning in IV grade students of elementary school Gugus II Kuta Utara academic year 2017/2018. This is evidensed by the $\left(t_{\text {hitung }}=2,683>t_{\text {tabel }}=2,021\right)$ at the significant of $5 \%$ with $d k n 1+n 2-2(30+30-2=56)$ and the average competency value of mathematics knowledge of students experimental group 73,50 and the average of competence value of mathematic knowledge of student control group 64,40. Thus, it can be concluded that the application of discovery learning model besed portofolio influence the knowledge competence of mathematics IV grade in elementary school Gugus II Kuta Utara academic year 2017/2018.
\end{abstract}

Keywords: discovery learning, portofolio, mathematical 


\section{Pendahuluan}

Pendidikan merupakan bagian penting dari proses pembangunan nasional yang ikut menentukan pertumbuhan ekonomi suatu negara. Dalam inilah pendidikan diperlukan dan dipandang sebagai kebutuhan dasar bagi masyarakat yang ingin maju. Untuk itu dengan adanya sistem pendidikan yang baik akan dapat meningkatkan mutu pendidikan untuk melahirkan sumber daya manusia (SDM) yang berkualitas. Pendidikan juga merupakan usaha sadar dan terencana untuk mewujudkan suasana belajar dan proses pembelajaran agar peserta didik secara aktif mengembangkan potensi dirinya untuk memiliki kekuatan spritual keagamaan, pengembangan diri, kepribadian, kecerdasan, akhlak mulia, serta keterampilan yang diperlukan dirinya, masyarakat, bangsa dan negara.

Dalam Lampiran Permendikbud No. 81A Tahun 2013 tentang Implementasi Kurikulum Pedoman Umum Pembelajaran dijelaskan bahwa "kegiatan pembelajaran merupakan proses pendidikan yang memberikan kesempatan kepada siswa untuk mengembangkan potensi dalam hal sikap, pengetahuan, dan keterampilan". Kegiatan pembelajaran harus diarahkan untuk memfasilitasi pencapaian kompetensi yang telah dirancang dalam kurikulum agar setiap siswa mampu menjadi pembelajar mandiri sepanjang hayat.

Peranan dan fungsi kurikulum menyesuaikan dengan keberadaan manusia yang selalu menghadapi perubahan. Pembelajaran kurikulum 2013 dilaksanakan melalui Pendekatan Saintifik untuk memberikan pemahaman kepada siswa dalam mengenal, memahami berbagai materi menggunakan pendekatan ilmiah, bahwa informasi bisa berasal dari mana saja, tidak tergantung pada informasi searah dari guru. Dalam Permendikbud No. 81 tahun 2013 lampiran IV, "proses pembelajaran saintifik terdiri atas lima langkah pembelajaran yaitu mengamati, menanya, menalar, mengasosiasi, dan mengomunikasikan". Pada intinya, pendekatan saintifik merupakan pendekatan di dalam kegiatan pembelajaran yang mengutamakan kreativitas dan temuan-temuan siswa.

Dalam pembelajaran terutama mata pelajaran matematika siswa tidaklah hanya harus menghafal rumus-rumus saja ataupun guru mensajikan lansung suatu konsep dalam bentuk jadi (finalnya). Tetapi siswa diharapkan menemukan sendiri konsep pengetahuannya. Dalam model discovery learning siswa di tuntut untuk lebih aktif dalam proses pembelajaran dan menemukan sendiri konsep pengetahuan yang tidak disajikan dalam bentuk akhir oleh guru, namun peserta didik dituntut untuk melakukan berbagai kegiatan menghimpun informasi, membandingkan, mengategorikan, menganalisis, mengintegrasikan, dan membuat kesimpulan-kesimpulan. Untuk mendukung semua itu dalam proses penilaian sangatlah penting untuk mengetahui pengembangan dari masing-masing siswa. Dalam penerapan model discovery learning proses pembelajaran juga menggunakan portofolio. Menurut Samatowa (2011) portofolio adalah kumpulan koleksi hasil kerja siswa yang disimpan dalam suatu map atau boks. Portofolio menunjukan tidak hanya hasil belajar tetapi juga upaya yang telah dilakukan peserta didik dalam mencapai belajar, proses yang telah dilalui peserta didik serta kemajuan yang diperoleh dari upaya dan proses yang dijalani dari hari ke hari. Data itu bisa dijadikan dasar bagi guru untuk memperbaiki metode, strategi, serta manajemen pembelajaran. Guru juga bisa memantau kemajuan siswa dari hari ke hari dan mendorong siswa merefleksikan pembelajaran mereka sendiri.

Berdasarkan observasi yang dilakukan pada SD Gugus II Kuta Utara khususnya pada kelas IV mata pelajaran Matematika ditemukan bahwa nilai Matematika siswa masih ada yang dibawah KKM (kriteria ketuntasan minimal) yaitu 70. Dari total keseluruhan SD yang ada di Gugus II Kuta Utara, siswa yang belum tuntas mencapai $51,62 \%$ atau 143 siswa dari 277 siswa, sedangkan siswa yang sudah tuntas mencapai $48,37 \%$ atau hanya 134 siswa dari 277 siswa. Dalam proses pembelajaran di SD tersebut sudah diterapkannya kurikulum 2013 menggunakan pembelajaran konvensional dengan pendekatan saintifik tetapi belum diterapkannya model pembelajaran yang mengacu pada kurikulum 2013 sehingga siswa masih kurang aktif dalam mengikuti kegiatan pembelajaran dan kurang optimalnya pemahaman siswa dalam pembelajaran Matematika yang menyebabkan siswa masih ada yang mendapatkan nilai Matematika di bawah KKM. Dalam proses kegiatan pembelajaran 
juga guru tidak melihat proses siswa dalam menyelesaikan, menemukan, ataupun mengembangkan pengetahuannya.

Dengan demikian, dari permasalahan tersebut melalui model discovery learning berbasis portofolio, guru dapat memantau kemajuan siswa dari hari kehari dan mendorong siswa merefleksikan pembelajaran mereka sendiri. Dan di dalam proses pembelajaran pun partisipasi siswa dapat meningkat, serta siswa lebih aktif, senang dan termotivasi di dalam pembelajaran karena siswa dapat menemukan dan memahami suatu konsep pengetahuan dari apa yang ditemukan tersebut. Sehingga kompetensi matematika siswa juga dapat meningkat.

Hal ini juga didukung dengan adanya penelitian oleh Sari (2017) yang mengatakan bahwa penerapan model discovery learning dalam pembelajaran matematika terbukti dapat meningkatkan kompetensi pengetahuan matematika. Nilai rata-rata yang diperoleh siswa pada kelompok eksperimen lebih tinggi dibandingkan kelompok kontrol $(12,91>10,76)$.

Berdasarkan uraian latar belakang tersebut, adapun tujuan yang ingin dicapai dalam penelitian ini yaitu sebagai berikut. 1) Untuk mengetahui kompetensi pengetahuan matematika kelompok siswa yang dibelajarkan melalui model discovery learning berbasis portofolio pada siswa kelas IV SD Gugus II Kuta Utara Tahun Pelajaran 2017/2018. 2) Untuk mengetahui kompetensi pengetahuan matematika kelompok siswa yang dibelajarkan melalui pembelajaran konvensional pada siswa kelas IV SD Gugus II Kuta Utara Tahun Pelajaran 2017/2018. 3) Untuk mengetahui pengaruh model discovery learning berbasis portofolio terhadap kompetensi pengetahuan matematika siswa kelas IV SD Gugus II Kuta Utara Tahun Pelajaran 2017/2018.

\section{Metode}

Penelitian ini dilakukan di Gugus II Kuta Utara tahun pelajaran 2017/2018. Dalam SD Gugus II Kuta Utara terdiri dari 7 sekolah dengan 9 kelas, sekolah yang di jadikan kelas eksperimen yaitu SD No. 3 Canggu dan sekolah yang dijadikan kelas Kontrol yaitu SD No. 1 Tibubeneng (IVC).

waktu penelitian ini dilaksanakan pada bulan Maret sampai dengan bulan April 2018. Perlakuan diberikan sebanyak 6 kali di kelompok eksperimen dan 6 kali di kelompok kontrol. Jumlah perlakuan yang diberikan telah disesuaikan dengan jam pelajaran terkait materi dalam penelitian ini telah diatur dalam kurikulum.

Tujuan penelitian ini adalah untuk mengetahui pengaruh model discovery learning berbasis portofolio terhadap kompetensi pengetahuan matematika siswa kelas IV SD Gugus II Kuta Utara Tahun Pelajaran 2017/2018. Jenis penelitian ini adalah penelitian ekperimen semu dengan rancangan nonquivalent control group design (Sugiyono, 2013:79).

Sebelum dilakuakan penelitian dilakukan penyetaraan kelompok terlebih dahulu. "Pemberian pre-test biasanya digunakan untuk mengukur equivalensi atau penyetaraan kelompok" (Dantes, 2012: 97). Berdasarkan hal tersebut, maka dalam penelitian ini pre-test digunakan untuk menyetarakan kelompok.

Dalam melakukan sebuah penelitian harus ditentukan populasi yang akan digunakan. Menurut Agung (2014:69) "Populasi adalah keseluruhan objek dalam suatu penelitian". Menurut Sugiyono (2011:117), "populasi adalah wilayah generalisasi yang terdiri atas objek/subjek yang mempunyai kualitas dan karakteristik tertentu yang ditetapkan oleh peneliti untuk dipelajari dan kemudian ditarik kesimpulannya". Dan menurut Darmadi (2014:55) "Populasi adalah wilayah yang terdiri dari objek/subjek yang mempunyai kualitas dan karakteristik tertentu yang ditetapkan oleh peneliti guna dipelajari kemudian ditarik kesimpulannya untuk dijadikan sebagai sumber data dalam suatu penelitian". Jadi dapat disimpulkan populasi adalah keseluruhan objek/subjek yang mempunyai kualitas dan karakteristik tertentu di tetapkan oleh peneliti untuk dipelajari kemudian ditarik kesimpulan untuk dijadikan sumber data dalam suatu penelitian.

Populasi dari penelitian ini adalah seluruh kelas IV Sd Gugus II Kuta Utara Tahun Pelajaran 2017/2018, yang terdiri dari 9 kelas dalam 7 sekolah dasar. Jumlah populasi dari penelitian ini adalah 277 orang. 
Setelah mengetahui populasi, langkah selanjutnya adalah menentukan sampel penelitian. "Sampel adalah suatu kelompok yang lebih kecil atau bagian dari populasi secara keseluruhan" (Setyosari, 2013:221). "Sempel adalah bagian dari jumlah dan karakteristik yang dimiliki oleh populasi tersebut" (Sugiyono 2011:81). "Sampel adalah sebagian dari populasi yang diambil, yang dianggap mewakili seluruh populasi dan diambil dengan menggunakan teknik tertentu" (Agung, 2014:69). Jadi dapat disimpulkan sampel adalah kelompok yang lebih kecil atau bagian dari populasi secara keseluruhan yang diambil dengan menggunakan teknik tertentu.

Teknik atau cara untuk mengambil bagian dari populasi dinamakan teknik sampling. Teknik pengambilan sampel pada penelitian ini adalah Random Sampling yang diacak adalah kelas, sehingga setiap kelas mendapatkan peluang yang sama untuk menjadi sampel penelitian.

Sampel dalam penelitian ini adalah siswa kelas IV SD No. 3 Canggu berjumlah 30 siswa sebagai kelompok ekperimen dan siswa kelas IVC SD No. 1 Tibubeneng berjumlah 30 siswa sebagai kelompok kontrol.

"Variabel bebas adalah variabel yang menyebabkan atau memengaruhi, yaitu faktorfaktor yang diukur, dimanipulasi, atau dipilih oleh peneliti untuk menentukan hubungan antara fenomena yang diobservasi atau diamati" (Setyosari, 2013:164). "Variabel bebas adalah variabel yang mempengaruhi atau yang menjadi sebab perubahannya atau timbulnya variabel dependen atau terikat" (Sugiyono, 2013:39). Jadi dapat disimpulkan variabel bebas adalah variabel yang menyebabkan atau mempengaruhi perubahan atau timbulnya variabel terikat yang akan diamati. Variabel bebas dalam penelitian ini adalah Model Discovery Learning berbasis Portofolio.

"Variabel terikat adalah faktor-faktor yang diobservasi dan diukur untuk menentukan adanya pengaruh variabel bebas, yaitu faktor yang muncul, atau tidak muncul, atau berubah sesuai dengan yang diperkenalkan oleh peneliti itu" (Setyosari, 2013:165). "Variabel terikat adalah variabel yang dipengaruhi atau yang menjadi akibat, karena adanya variabel bebas" (Sugiyono, 2013:39). Jadi dapat disimpulkan variabel terikat adalah variabel yang dipengaruhi oleh variabel bebas. Variabel terikat dalam penelitian ini adalah kompetensi pengetahun Matematika siswa.

Data yang dikumpulkan dalam penelitian diperoleh dengan cara pemberian post-test setelah diberikan perlakuan berupa model discovery learning berbasis portofolio kepada kelompok ekperimen dan diberikan pembelajaran berupa pembelajaran konvensional kepada kelompok kontrol. Sebelum tes digunakan terlebih dahulu dilakukan validasi secara teoritis dengan menggunakan kisi-kisi dan dikonsultasikan pada ahli, selanjutnya dilakukan validasi secara empirik dengan jumlah responden 34 siswa. Dari hasil uji instrument yang meliputi uji validitas, uji reliabilitas, uji daya beda, dan uji indeks kesukaran diperoleh 30 butir tes yang dinyatakan layak digunakan dalam penelitian dari total 40 butir tes yang di uji cobakan.

Metode dan teknik analisis data yang dilakukan adalah menghitung analisis statistik deskriptif dan analisis statistik inferensial. Statistik deskriptif adalah statistik yang berfungsi untuk mendeskripsikan atau memberi gambaran terhadap objek yang diteliti melalui data sampel atau populasi sebagaimana adanya, tanpa melakukan analisis dan membuat kesimpulan yang berlaku untuk umum (Sugiyono, 2013:29). Pada statistik deskripsi ini untuk menghitung rata-rata (mean), menghitung standar deviasi dan varians. Statistik inferensial adalah suatu teknik pengumpulan data yang dilakukan dengan cara menerapkan rumusrumus statistik inferensial untuk menguji suatu hipotesis penelitian yang diajukan dan menarik kesimpulan berdasarkan hasil pengujian terhadap hipotesis (Agung, 2014).

Teknik yang digunakan untuk menganalisis kompetensi pengetahuan matematika dalam penelitian ini adalah dengan menggunakan analisis statistik yaitu uji-t. Sesudah dilaksanakannya uji prasyarat yang meliputi uji normalitas sebaran data dan uji homogenitas varians. Jika data yang diperoleh sudah memenuhi prasyarat uji normalitas dan homogenitas maka dapat analisis yang digunakan adalah statistik parametris. Analisis statistik yang digunakan untuk menguji hipotesis penelitian ini adalah uji beda mean (uji t). Uji Hipotesis menggunakan uji-t dengan rumus separated varians. Rumus uji-t dengan rumus separated 
varians digunakan bila jumlah anggota sampel sama $n_{1}=n_{2}$ dan varians homogen. Dengan kriteria pada taraf signifikansi $5 \%$ dengan $d k=n_{1}+n_{2}-2$. jika harga $t_{\text {hitung }} \leq t_{\text {tabel }}$, maka $H_{0}$ diterma, dan jika harga $t_{\text {hitung }}>t_{\text {tabel }}$, maka $H_{0}$ ditolak.

\section{Hasil dan Pembahasan}

. Penelitian ini merupakan quasi experiment atau eksperimen semu yang menggunakan rancangan nonequivalent control group design yang dianalisis menggunakan uji-t objek yang diteliti adalah kompetensi pengetahuan matematika kelas IV dari penggunaan model discovery learning berbasis portofolio dan tidak menggunakan model discovery learning berbasis portofolio.

Setelah diberikan perlakuan (treatment) menggunakan model discovery learning berbasis portofolio sebanyak 6 kali pada kelompok ekperimen, di akhir ekperimen siswa diberikan post-test untuk memperoleh data kompetensi pengetahuan matematika siswa. Nilai rata-rata kompetensi pengetahuan matematika kelas ekperimen yaitu 73,50 . Berdasarkan PAP maka nilai rata-rata kompetensi pengetahuan matematika siswa pada kelas ekperimen berada pada predikat Cukup.

Setelah diberikan pembelajaran dengan pembelajaran konvensional sebanyak 6 kali pada kelompok kontrol, di akhir kontrol siswa diberikan post-test untuk memperoleh data kompetensi pengetahuan matematika siswa. Nilai rata-rata kompetensi pengetahuan matematikakelas kontol yaitu 64,40. Berdasarkan PAP maka nilai rata-rata kompetensi pengetahuan matematika siswa pada kelas kontrol berada pada predikat Kurang.

Uji prasyarat dilakukan terlebih dahulu sebelum uji hipotesis menggunakan uji-t. Uji prasyarat tersebut meliputi uji normalitas dan uji homogenitas varians diuraikan sebagai berikut ini. Berdasarkan hasil uji normalitas kelompok ekperimen, diperoleh Chi Kuadrat hitung $\left(x^{2}\right.$ hitung $\left.=2,801\right)$ kemudian nilai tersebut dibandingkan dengan Chi Kuadrat tabel $\left(x^{2}\right.$ tabel $\left.=11,070\right)$. Hal ini menunjukan bahwa $x^{2}$ hitung $<x^{2}{ }_{\text {tabel }}$ berarti data hasil penguasaan kompetensi pengetahuan matematika kelompok ekperimen berdistribusi normal.

Berdasarkan hasil uji normalitas kelompok kontrol, diperoleh Chi Kuadrat hitung $\left(x^{2}\right.$ hitung $=8,459)$ kemudian nilai tersebut dibandingkan dengan Chi Kuadrat tabel $\left(x^{2}{ }_{\text {tabel }}=11,070\right)$. Hal ini menunjukan bahwa $x^{2}$ hitung $<x^{2}$ tabel berarti data hasil penguasaan kompetensi pengetahuan matematika kelompok kontrol berdistribusi normal. Pengujian homogenitas varians antar kelompok dimaksudkan untuk meyakinkan bahwa perbedaan yang diperoleh uji-t benar-benar berasal dari perbedaan antara kelompok bukan disebabkan oleh perbedaan di dalam kelompok. Uji homogenitas varians yang dilakukan dalam penelitian ini menggunakan uji $F$. Dari hasil analisis, diperoleh $F_{\text {hitung }}=1,30$ dan $F_{\text {tabel }}=1,90$. Hal ini berarti $F_{\text {hitung }}<F_{\text {tabel, }}$ sehingga data kedua kelompok memiliki varians yang homogen.

Berdasarkan hasil uji prasyarat yang terdiri dari uji normalitas dan uji homogenitas varians, disimpulkan bahwa kedua kelompok sampel ialah berdistribusi normal dan memiliki varians yang homogen. Dengan demikian, uji hipotesis menggunakan uji-t dapat dilakukan. Hipotesis penelitian yang diuji dalam penelitian ini adalah hipotesis nol (Ho) yang berbunyi Tidak terdapat perbedaan yang signifikan kompetensi pengetahuan matematika kelompok siswa yang dibelajarkan menggunakan model discovery learning berbasis portofolio dan kelompok siswa yang dibelajarkan menggunakan pembelajaran konvensional pada siswa kelas IV SD Gugus II Kuta Utara Tahun Pelajaran 2017/2018.

Berdasarkan hasil uji normalitas sebaran data dan uji homogenitas varians dapat diketahui bahwa data yang diperoleh dari kelompok eksperimen dan kelompok kontrol berdistribusi normal dan memiliki varians yang homogen. Karena data yang diperoleh telah memenuhi uji prasyarat, maka uji hipotesis dapat dilakukan dengan menggunakan uji-t. Berikut disajikan rekapitulasi hasil analisis data dengan menggunakan uji-t pada Tabel 1. 
Tabel 1. Rekapitulasi Aanalisis Uji-t

\begin{tabular}{|c|c|c|c|c|c|c|c|c|}
\hline No & Sampel & $\mathbf{N}$ & $\mathbf{d k}$ & $\bar{X}$ & $\mathbf{S}^{2}$ & $\mathbf{t}_{\text {hitung }}$ & $\mathbf{t}_{\text {tabel }}$ & Status \\
\hline 1 & $\begin{array}{l}\text { Kelompok } \\
\text { eksperimen }\end{array}$ & 30 & & 73,50 & 150,07 & & & \multirow{2}{*}{58} \\
\cline { 1 - 2 } 2 & $\begin{array}{l}\text { Kelompok } \\
\text { kontrol }\end{array}$ & 30 & 58 & 64,40 & 195,14 & 2,683 & 2,021 & $\begin{array}{c}\mathrm{H}_{0} \\
\text { ditolak }\end{array}$ \\
\hline
\end{tabular}

Dari hasil analisis diperoleh $t_{\text {hitung }}=2,683$ dan $t_{\text {tabel }}=2,021$ pada taraf signifikansi $5 \%$ denga $\mathrm{dk}=\mathrm{n}_{1}+\mathrm{n}_{2}-2=30+30-2=58$. Oleh karena $t_{\text {hitung }}=2,683>\mathrm{t}_{\text {tabel }}=2,021$ maka Ho yang menyatakan tidak terdapat perbedaan yang signifikan kompetensi pengetahuan matematika kelompok siswa yang dibelajarkan menggunakan model discovery learning berbasis portofolio dan kelompok siswa yang dibelajarkan menggunakan pembelajaran konvensional pada siswa kelas IV SD Gugus II Kuta Utara ditolak, dan berati Ha yang menyatakan bahwa terdapat perbedaan yang signifikan kompetensi pengetahuan matematika kelompok siswa yang dibelajarkan menggunakan model discovery learning berbasis portofolio dan kelompok siswa yang dibelajarkan menggunakan pembelajaran konvensional pada siswa kelas IV SD Gugus II Kuta Utara diterima.

Perbedaan yang signifikan kompetensi pengetahuan matematika siswa yang dibelajarkan menggunakan model discovery learning berbasis portofolio disebabkan karena model pembelajaran ini merupakan suatu inovasi pembelajaran yang mendorong siswa untuk berpikir dan menemukan sendiri suatu konsep yang sedang dipelajarinya, sehingga siswa dapat memahami benar dan siswa dapat mengingat lebih lama dari apa yang telah ditemuinya tersebut. Dalam penerapan model discovery learning proses pembelajaran juga menggunakan portofolio, sehingga didalam kegiatan pembelajaran siswa dapat mengumpulkan hasil yang telah dikerjakan pada suatu map, dalam proses pembelajaranpun guru dapat memantau perkembangan pengetahuan, ketrampilan, dan sikap peserta didik. Widiasworo (2017) menyatakan bahwa kelebihan dari model discovery learning adalah menimbulkan rasa senang pada peserta didik karena tumbuhnya rasa menyelidiki dan berhasil, menyebabkan peserta didik mengarahkan kegiatan belajarnya sendiri dengan melibatkan akalnya dan motivasi sendiri, peserta didik akan mengerti konsep dasar dan ideide lebih baik, membantu dan mengembangkan ingatan dan transfer kepada situasi proses belajar yang baru, mendorong peserta didik berpikir dan bekerja atas inisiatif sendiri dan dapat mengembangkan bakat dan kecakapan individu.

Dengan demikian, hasil kompetensi pengetahuan matematika dapat terlihat dari kegiatan pembelajaran yang dilakukan pada kelompok ekperimen tersebut, hasil analisis uji hipotesis, dan nilai rerata kelompok siswa yang mengikuti pembelajaran menggunakan model discovery lerning berbasis portofolio dengan siswa yang mengikuti pembelajaran menggunakan pembelajaran konvensional.

Hasil temuan pada penelitian ini memiliki persamaan dengan penelitian sebelumnya yang relevan dan memperkuat peneliatian yang diperoleh, hal tersebut didukung hasil penelitian yang diajukan oleh Candra (2017) dengan hasil penelitian yang menyatakan, terdapat perdedaan antara kelompok siswa yang dibelajarkan dengan model discovery learning dengan kelompok siswa yang dibelajarkan dengan pembelajaran konvensional. Berdasarkan paparan tersebut, dapat dikatakan bahwa model discovery learning berbasis portofolio berpengaruh terhadap kompetensi pengetahuan matematika siswa kelas IV SD Gugus II Kuta Utara.

\section{Simpulan dan Saran}

Berdasarkan hasil analisis data kompetensi pengetahuan matematika pada kelompok ekperimen terdapat 30 orang siswa dengan nilai tertinggi 93 dan nilai terendah 46. Dari sebaran data tersebut diperoleh rata-rata (mean) sebesar 73,50 dan termasuk predikat Cukup. 
Berdasarkan hasil analisis data kompetensi pengetahuan matematika pada kelompok kontrol terdapat 30 orang siswa dengan nilai tertinggi yang diperoleh 93 dan nilai terendah adalah 40. Dari sebaran data tersebut diperoleh rata-rata (mean) sebesar 64,40 dan termasuk predikat kurang.

kan hasil penelitian yang diperoleh terdapat perbedaan yang signifikan kompetensi pengetahuan matematika kelompok siswa yang dibelajarkan menggunakan model discovery learning berbasis portofolio dan kelompok siswa yang dibelajarkan menggunakan pembelajaran konvensional kelas IV SD Gugus II Kuta Utara Tahun Pelajaran 2017/2018, dengan nilai $t_{\text {nitung }}=2,683>t_{\text {tabel }}=2,021$ untuk signifikansi $5 \%$ dan derajat kebebasan 58 . Dengan demikian model discovery learning berbasis portofolio berpengaruh terhadap kompetensi pengetahuan matematika siswa kelas IV SD Gugus II Kuta Utara Tahun Pelajaran 2017/2018.

Adapun saran yang ingin disampaikan melalui penelitian ini yaitu: (1) kepada guru agar lebih kreatif untuk memberikan fasilitas berupa sumber belajar dan kesempatan yang lebih besar bagi siswa pada pembelajaran dengan menggunakan model discovery learning berbasis portofolio sehingga tercipta pembelajaran bermakna dan menyenangkan bagi siswa. (2) kepada kepala sekolah agar dapat menggunakan hasil penelitian ini sebagai pendukung sumber belajar guru dalam meningkatkan kualiatas pembelajaran dengan menciptakan pembelajaran yang menyenangkan di sekolah sehingga sekolah mampu menghasilkan siswa yang berkualitas. (3) kepada peneliti agar hasil penelitian ini digunakan sebagai referensi untuk melaksanakan penelitian selanjutnya atau menemukan inovasi kegiatan pembelajaran lainnya yang bermakna dan menyenangkan bagi siswa.

\section{Daftar Pustaka}

Agung, A.A. Gede. 2014 Metodologi Penelitian Pendidikan. Malang: Aditya Media Publishing.

Candra, Anak Agung Bagus Trisna Adi. 2017. Pengaruh Model Discovery Learning Terhadap Kompetensi Pengetahuan IPA Siswa Kelas VI SD Gugus Yos Sudarso Kecamatan Denpasar Selatan. Vol 5 No 2. E-journal PGSD Universitas Pendidikan Ganesha. (diakses pada tanggal 28 Februari 2018).

Dantes, Nyoman. 2012. Metode Penelitian. Yogyakarta: Andi

Darmadi, Hamid. 2014. Metode Penelitian Pendidikan dan Sosial. Bandung: Alfabeta.

Kosasih. 2014. Strategi Belajar dan Pembelajaran Implementasi Kurikulum 2013. Bandung: Yrama Widya.

Permendikbud. 2013. Nomor 81A Tentang Implementasi Kurikulum Dengan Rahmat Tuhan Yang Maha Esa. Jakarta: Permendikbud.

Permendikbud. 2014. Nomor 57 Tentang Kurikulum 2013 Sekolah Dasar/Madrasah Ibtidaiyah. Jakarta: Permendikbud.

Sari, Ni Made Meita Purnama. 2017. Pengaruh Model Discovery Learning Terhadap Hasil Belajar Matematika Siswa Pada Kelas V Sd Gugus II Kecamatan Mendoyo. Vol 5 No 2. E-journal PGSD Universitas Pendidikan Ganesha. (diakses pada tanggal 28 Februari 2018).

Setyosari, Punaji. 2013. Metode Penelitian Pendidikan \& Pengembangan. Jakarta: Kencana. 
Indonesian Journal Of Educational Research and Review, Vol. 1 No. 2, Juli 2018

P-ISSN: 2621-4792, E-ISSN: 2621-8984

Sugiyono. 2011. Metode Penelitian Pendidikan Pendekatan Kuantitatif, Kualitatif, dan R\&B. Bandung: Alfabeta.

Sugiyono. 2013. Metode Penelitian Pendidikan Pendekatan Kuantitatif, Kualitatif, dan R\&B. Bandung: Alfabeta. 